\title{
AGNIESZKA JANIEC-NYITRAI
}

Uniwersytet im. L. Eötvösa w Budapeszcie

Wydział Humanistyczny

\section{ŠEDÁ ZÓNA MEZI ZÁMĚREM A ČINEM ANEB PÁR ÚVAH O PARADOXNOSTI LIDSKÝCH PLÁNU゚ V PROZAICKÉ TVORBĚ MILANA KUNDERY}

Cílem tohoto článku je nabídnout trochu jiný pohled na prozaickou tvorbu Milana Kundery a zamyslet se nad otázkami paměti, lidských činů jako předmětu neustálých interpretací a reinterpretací, a v neposlední řadě také lidské totožnosti a svobody lidského rozhodování. Využijeme mj. také teorii kulturního zapomínání jako jedné ze strategií budování vlastní identity a subjektivity. Už na začátku je třeba zdůraznit, že Kundera od 60. let minulého století ve své tvorbě řešil otázky, které se staly předmětem zájmu memory studies, a tímto Kundera předběhl boom pamětových studií, tak populárních už několik let.

Podle Milana Kundery je člověk odkázán na věčnou nejistotu a tápání, protože jak autor píše: „[...] žije jen jeden život a nemůže ho nijak porovnat se svými předchozími životy, ani ho opravit v následujících životech“" nebude dokončena, která je pouhým plánem, nezávazným pokusem vznikajícím bez možnosti oprav. Lidský život je krutě „daný“; vždyt’ žijeme pouze jednou a ihned „načisto“. Všechno musíme udělat už na první pokus, který je zároveň pokusem posledním, což dává lidskému životu nesnesitelnou tíhu.

Každé slovo, které bylo vyřčeno, každá báseň, která byla zveřejněná, každý milostný dopis, který leží v něčí zásuvce, se vyznačují velkou tíhou. Jsou viditelnými znaky minulosti, které nejde spálit, retušovat ani odčinit. Už je jednou někdo přečetl, už je jednou někdo viděl, takže si na ně jednou určitě někdo vzpomene. Vše - gesto, čin, mlčení, slovo, písmeno - podléhá interpretacím. Mirek z Knihy smíchu a zapomnění chce marně zpátky získat své dopisy a s hrůzou si uvědomuje, že člověk, který je kdysi napsal (čili přece on sám před několika lety!), se mu mezitím strašně odcizil. Není s to akceptovat, že není statickou entitou, ale podléhá proměnám. Čin, který byl jednou „spáchán“, bude vždy svědčit proti nám. Proto hrdina Kunderova románu chce vymazat tu část své minulosti (ženu, kterou miloval a za kterou se ted' stydí), aby mohl napsat to, co už bylo napsáno, znovu, podobným způsobem, jako komunisté retušovali fotografie, a tak chtěli zpětně retu-

\footnotetext{
1 M. Kundera, Nesnesitelná lehkost bytí, Brno 2006, s. 16.
} 
šovat minulost ${ }^{2}$. To, co se však jednou stalo, je velmi obtížně vymazatelné a je v podstatě neodčinitelné.

Kundera je k „,pomyslným egům“ svých literárních postav mimořádně krutý, nedává jim zapomenout na to, co je pro ně zdrojem utrpení, nutí je neustále si připomínat porážky, chyby a nezdary. Zapomnění hraje velmi důležitou roli v makro a mikro měřítku - je podstatné jak pro celé společnosti, tak pro individua, o čemž píše Paul Connerton ve své typologii sedmi typů zapomnění ${ }^{3}$. Zapomnění může totiž znamenat další krok dopředu ve vývoji lidské identity, může být blahodárné a neznamená zároveň popření sebe sama. Zapomnění je dokonce, jak konstatuje Paul Connerton, nutné k formování identity, je nezbytné k tomu, aby jisté traumatické zkušenosti nezabrzdily přirozený, dynamický vývoj člověka. Zapomínání je přirozenou součástí procesů pamatování a utváření (se) lidské identity. Nahlížené touto optikou jednorázovost a opakování ztrácejí svůj význam, který jim Kundera přisuzuje.

Právě mezi jednorázovostí a opakováním je zavěšen trpký úděl Taminin. Hlavní hrdinka Knihy smíchu a zapomnění jen jednou přikývla na „erotickou blízkost“ s Hugem, a i nadále v ní musí pokračovat: „[...] těžko mu mohla odepírat, co mu jednou povolila“4 . Do podobné pasti souhlasu padla také Markéta, další postava Kunderovy románové mozaiky z Knihy smíchu a zapomnění, když přišlo na rozdělování rolí v manželství:

Každý milostný vztah spočívá na nepsaných úmluvách, které milenci uzavřou neprozřetelně v prvních týdnech lásky. [...] Už v prvních týdnech se mezi Karlem a Markétou rozhodlo, že Karel bude nevěrný a Markéta se $\mathrm{s}$ tím smírí, že však Markéta bude mít právo být tou lepší a Karel se bude před ní cítit vinen 5 .

Výstižná je v tomto kontextu Kunderou užívaná metafora tance v kruhu. Pokud člověk jednou vstoupí do kruhu tanečníků, pak jen velmi obtížně může měnit rytmus či melodii tance. Navždy bude muset respektovat to, co tančí jiní. Stává se „poskvrněn“ svým činem, nemůže se vrátit zpátky do původního stavu „neposkvrněného početí“. Snad jen částečně ho může vysvobodit kunderovský d'ábelský smích, který však znamená vystoupení z kruhu, a porušení pravidel hry. Ne každý člověk je s to porušit pravidelnost kruhu a pokračuje v tanci veden dostředivou silou. To, co mělo být pouze chvilkové, najednou získává nebezpečnou tíhu zvyků, rituálů, které se pak mohou donekonečna opakovat.

Člověk by chtěl věřit v refrén, který se často objevuje v Nesnesitelné lehkosti bytí, v německé úsloví „einmal ist keinmal““. „Smí-li člověk žít jen jeden život, je to, jako by nežil vůbec“6. Takto vzniká podivuhodná kombinace lehkosti a tíhy života. Člověk je na jedné straně jakoby zbaven zodpovědnosti za své činy, ale zároveň je mu vždy blízký tíživý pocit nenávratnosti a neodčinitelnosti toho, co se jednou stalo. Nikdy neví, zda jeho rozhodnutí, která se v jistém okamžiku zdají být správná a oprávněná, budou vždy takto hodnocena. „Každý školák může v hodinách fyziky dělat pokusy, aby se přesvědčil o tom, je-li určitá vědecká hypotéza pravdivá. Ale člověk, protože žije jen jeden život, nemá žád-

\footnotetext{
2 E. Le Grand, Kundera aneb Pamět’ touhy, Olomouc 1998, s. 63.

${ }^{3}$ P. Connerton, Seven Types of Forgetting, „Memory Studies“ 2008, č. 1, s. 59-71.

${ }^{4}$ M. Kundera, Kniha smichu a zapomnění, Toronto 1981, s. 122.

${ }^{5}$ Ibidem, s. 43.

${ }^{6}$ Idem, Nesnesitelná lehkost bytí, op. cit., s. 17.
} 
nou možnost ověřit hypotézu pokusem, a nikdy se proto nedoví, zda měl poslechnout svůj cit"7. Jistá(,) konkrétní rozhodnutí vylučují pokračování života jiným směrem, uzavírají určité cesty, proto nikdy neexistuje stoprocentní jistota, že cesta, kterou člověk zvolil, je ta nejsprávnější. Podstatnou v tomto ohledu je také etická zodpovědnost člověka za jeho vlastní činy, která je nivelizována právě onou lehkostí, jednorázovostí, nemožností vrátit zpátky jednou vyřčená slova či učiněná gesta a v neposlední řadě také nahodilostí lidských činů. Tíha totiž znamená metafyzické břemeno, pocit zodpovědnosti a povinnosti vůči druhému člověku ${ }^{8}$. Kontingence podle Kundery neruší však lidskou morální zodpovědnost. Nutnost a „terminovanost“ jsou součástí života, „es muss sein“ doplňuje s Beethovenem Kundera a staví tento výrok do protikladu k „einmal ist keinmal“. Podle polského filozofa Stefana Morawského Kundera paradoxně, i přestože ukazuje jednorázovost lidského života, zdůrazňuje existenci nutnosti, nezbytnosti lidské morální potřeby jednat podle předjednaných pravidel. Tato nutnost jako pavučina obepíná lidský život a patř́i k nezbytné součásti lidského bytí .

Květoslav Chvatík právě v této, u Kundery mnohokrát zdůrazňované, neodvratnosti a neodčinitelnosti lidského osudu spatřuje hlavní rozdíl mezi existencí př́rody a bytím člověka ${ }^{10}$. Žijeme na planetě nezkušenosti (tak koneckonců zněl původní název Kunderova románu Nesnesitelná lehkost bytí), kde jsme odkázáni k osudovým chybám, které nejsme schopni odčinit - „es muss sein“. Proto, jak píše Justyna Kościukiewicz, v každém lidském gestu, v každém lidském činu spočívá tíha nesnesitelné zodpovědnosti, podle níž se svět, který popisuje Kundera, zakládá na nenávratnosti ${ }^{11}$. Opět je zde vidět v oslnivé zřetelnosti Kunderovu paradoxnost: to, že nic nemůžeme změnit, nás zbavuje zodpovědnosti za naše činy, ale zároveň víme, že nám žádná chyba nebude odpuštěna, protože ji nejde odčinit. Vidíme zde jistý „teror činu“, činu, který nikdy nebude odčinitelný. Je s tím také spojen „teror paměti“،, nemožnost zapomenout na to, co bylo, a „teror všudyprrítomné minulosti“", která stále člověka obtěžuje, vydírá a nedovoluje normálně existovat.

V úvodních větách románu Nesnesitelná lehkost bytí se Kundera vrací k mýtu věčného návratu, o němž psal Nietzsche. Tento mýtus může mít trojí výklad, jak uvádí Paweł Pieniążek, byl totiž interpretován 1) ve smyslu kosmologicko-cyklickém jako návrat identických náhod, 2) jako věčný návrat ve smyslu etickém, jako postulát takového života, aby jej člověk chtěl opakovat, 3) jako věčný návrat ve smyslu věčného stávání se ${ }^{12}$. Podle polského badatele se v celé nejasné a komplikované, nekompletní a různě interpretované ideji věčného návratu dostává do popředí ontologická vzájemná závislost dění, časové omezenosti a nahodilosti lidského života, utrpení a zla, rozdílu mezi tím, co je důstojné a co důstojné není ${ }^{13}$. K podobným závěrům ve svých úvahách dospívá také Kundera, který

7 Ibidem, s. 43.

${ }^{8}$ S. Morawski, Wyciag z Kundery i kilka o jego dziele domystów, „Sztuka i filozofia“ 1996, č. 12, s. 5-6.

9 Ibidem, s. 6.

${ }^{10}$ K. Chvatík, Romány Milana Kundery a krize jazyka, „Tvar“ 1990, č. 5, s. 5.

11 J. Kościukiewicz, Wieczny powrót w twórczości Milana Kundery, [v:] Odbicie ważnych wydarzeń historycznych $w$ języku $i$ w literaturze czeskiej, red. M. Balowski, Poznań 2010, s. 208.

12 P. Pieniążek, Problem wiecznego powrotu w filozofii Fryderyka Nietzschego, „Acta Universitatis Lodziensis. Folia Philosophica“" 1988, č. 5, s. 185.

13 Ibidem, s. 201. 
zdůrazňuje, že v životě, který mizí v nedohlednu, který se nikdy nevrátí, dochází k nivelizaci toho, co je hrozné, a toho, co je krásné. Mezi tím, co je krásné, a tím, co je ošklivé, může docházet $\mathrm{k}$ výměně. Pomíjivost stírá rozdíly mezi věcmi, mezi hodnotami, i když z etického hlediska to není správné ${ }^{14}$.

Jedním z klíčových pojmů s tím spojených je nezkušenost, kterou Kundera vysvětluje jako:

[...] základní vlastnost lidského bytí. Narodíme se jednou provždy, nemůžeme nikdy začít jiný život se zkušenostmi předchozího života. Vystoupíme z dětství, aniž víme, co je mládí, vstoupíme do manželství, aniž víme, co je to manželství, a i když vcházíme do stáří, nevíme, kam jdeme: starý člověk je nevinné dítě svého stáří. V tom smyslu je tato země planetou nezkušeno$\operatorname{sti}^{15}$.

Jak bylo výše zmíněno, právě pomocí tohoto klíčového pojmu - planeta nezkušenosti - měl Kundera pojmenovat svůj román, který mu pak přinesl mezinárodní slávu a uznání. Tento motiv osudné nezkušenosti je rozvíjen v Tomášově uvažování o podstatě opakování:

Ve vesmíru existuje planeta, kde se všichni lidé narodí podruhé. Budou si přitom plně vědomi svého života stráveného na Zemi, všech zkušeností, které tam nabyli. A existuje možná dalši planeta, kde se všichni narodíme potřetí se zkušeností obou předchozích životů. A možná existují ještě další a další planety, kde se bude rodit lidstvo vždycky o jeden stupeň (o jeden život) zralejší. To je Tomášova verze věčného návratu. My ovšem zde na Zemi (na planetě číslo jedna, na planetě nezkušenosti) se můžeme jen zcela nejasně domýšlet, co by se stalo s člověkem na dalších planetách. Byl by moudřejší? Je vůbec zralost v moci člověka? Může ji dosáhnout opakováním? ${ }^{16}$.

Člověk se nemůže stát „ک̌remeslníkem“ života, je odkázán k tomu, aby hned na první pokus udělal svůj život co nejlepším, nejkrásnějším, nejhodnotnějším.

Jak literární věda interpretuje mýtus o věčném návratu? Odpověd’ můžeme najít u Tomáše Kubíčka:

Nietzscheho mýtus o věčném návratu je momentem odmítnutí dějin a tedy hodnot. V opakování dějin se vytrácí jedinečnost činu, jedinečnost lidského života, jeho tíha se stává lehkostí a jeho lehkost se stává tíhou. Princip binarity, na němž funguje společnost, na němž společnost definuje svůj smysl, se stává nejasným. Dochází k rozpadu hodnot. To slovo u Kundery nezazní. Je ale dostatečně zřetelně vytečkováno vyslovenými opozicemi světlo - tma, lehkost - tíže, teplo chlad $^{17}$.

Je zde zdůrazněn moment uplynutí, nivelizace všeho, co je evropskou civilizací uznáváno za hodnotu. Rozkolísání významů, pohyblivost struktury lidského světa, neustálá fluktuace idejí prozrazují, že se svět změnil v chaotickou směsici, kde vše může podléhat relativizování.

14 M. Kundera, Kastrujici stín svatého Garty, Brno 2006, s. 13.

15 Idem, Slova, pojmy, situace, Brno 2014, s. 27.

16 Idem, Kastrujici stín svatého Garty, op. cit., s. 239.

17 T. Kubíček, Kunderova estetická koncepce středoevropského románového dédictví. Základy, [v:] Cizinec vyhnanec - př́stěhovalec, red. Z. Zemánová, L. Pořízková, Olomouc 2012, s. 296. 
Otázku kontingence, objevující se také v kontextu jednorázovosti a opakování, jsme již načrtli výše a nyní se jí budeme věnovat podrobně, protože téma činu a kontextu, v němž se onen čin nachází, problematika záměrnosti a nahodilosti patří ke klíčovým problémům Kunderových próz už od sbírky Směšné lásky. Kundera se stále vrací k otázce týkající se zodpovědnosti za lidské činy, ale pokaždé, v každém ze svých románů, autor nabízí pouze jednu odpověd’: „Člověk se nemůže vyvázat ze zodpovědnosti za důsledky svých činů, ani když nedokáže ovlivňovat či kontrolovat proměňující se kontext, který pozměňuje i povahu jeho činư “18. Sít’ nahodilostí, do níž je chycen lidský život, neospravedlňuje člověka v jeho neustálém chybování, tápání, nezbavuje ho zodpovědnosti za své činy, nemění jejich váhu, nečiní je lehčími. Tato problematika se stává výrazným tématem povídek ze sbírky Směšné lásky - člověk je součástí hry, je zesměšněn ve svých plánech. Hraje hru, která nevyšla, hru, která obnažuje ${ }^{19}$. Plány, pečlivě propracované a do detailů promyšlené, se v určitém okamžiku zvrhávají a mění se ve svůj vlastní opak. Čin je něčím, co činí člověka člověkem a odlišuje ho od zvířat. Samotný Kundera považuje pojem „čin“ ve své tvorbě za podstatný. Zařadil ho dokonce do svého slovníku slov a pojmů:

Ale právě v takovém světě se narodil román. Jako kdysi epopej i on je založen na činu. Ale v románu je čin od počátku problematizován, doprovázen mnohonásobným tázáním: jestliže je pouhým důsledkem poslušnosti, je čin vůbec ještě čin? a jak rozlišit čin od repetitivních a rutinních gest? a co znamená slovo „svoboda“ v moderním zbyrokratizovaném světě, kde možnosti činu jsou tak nepatrné? ${ }^{20}$

Otázka př́íhodnosti, kterou řešil Kundera ve své tvorbě, byla přitažlivá i pro další západoevropské či světové intelektuály. V roce 1989 americký vědec Richard Rorty přichází s knihou Contingency, Irony and Solidarity, k níž koneckonců samotný autor jako úvodní citaci uvádí část Kunderova Umění románu pojednávající o křehkosti světa. Vliv Kundery na filozofické smýšlení amerického filozofa je nepřehlédnutelný. Rorty považuje Kunderu za svého oblíbeného spisovatele a vidí v něm autentického myslitele ${ }^{21}$. Rorty uvažuje o prŕíhodnosti, nahodilosti jazyka, ale pro pochopení díla Kundery dochází k zajímavým závěrům: nic z toho, co člověka obklopuje, se nedá představit nebo vyslovit prostřednictvím popisu vnitřní podstaty a esence ${ }^{22}$. Takto lze formulovat podstatu světa, člověka i jeho reakcí. Jazyk, který používáme, ale také naše samotné bytí, naše mentalita, naše touhy, konstrukce našeho nitra jsou výsledkem nahodilých setkání s ostatními, jsou výsledkem náhod, které se staly naším údělem, jsou tedy, logicky vzato, vždy nekonečné, vždy nehotové, otevřené dalším setkáním, která jsou ve své podstatě zcela náhodná. ${ }^{23}$ Člověk sám sebe stále znovu a znovu tvaruje pod vlivem jiných, mění se v nekonečném procesu setkávání,

18 Idem, Středoevropan Milan Kundera, Olomouc 2012, s. 101.

19 A. Haman, Hledání vlastního života, [v:] idem, Tři stálice moderní české prózy: Neruda, Čapek, Kundera, Praha 2014, s. 276.

20 M. Kundera, Slova, pojmy, situace, op. cit., s. 48.

21 S. Morawski, Wyciag z Kundery..., op. cit., s. 15.

${ }_{22}$ M. Kwiek, Richarda Rorty'ego postmodernistyczny świat ironii, „Kultura współczesna. Teoria - interpretacje - krytyka“" 1993, roč. 1, č. 1, s. 56-57.

${ }^{23}$ Zajímavý kontext $\mathrm{k}$ těmto úvahám poskytuje Kunderova editorská snaha dát svým textům, a také překladům svých textů konečnou neměnnou a ustálenou formu. Píše o tom mj. Jakub Češka (Ironiczna bezdomność Bohumila Hrabala a tlumiona tęsknota za domem Milana Kundery, „Porównania” 2012, roč. 11, č. 11, s. 92-93). 
plodného a ničivého kontaktu s ostatními lidmi, je vždy in statu nascendi a stále je vystaven proměnlivosti, nevypočitatelnosti a nahodilosti světa ${ }^{24}$. U Kundery je vidět všudypř́tomnou frustraci z toho, že jsme jako lidé tak nejednoznační, nejsme z jednoho kusu a nedokážeme sami sebe libovolně formovat podle svých představ. Podle Rortyho pravdu člověk vytvárí, neodhaluje ji. Pravda a skutečnost jsou jistým výsledkem, nikoli hotovou věcí. Člověk se s tím musí smírit, jinak bude žít v nekonečném klamu. Rorty ve svých dílech boří, podobně jako Kundera, názor, že svět je výtvorem boha, že se řídí nějakým vyšším smyslem ${ }^{25}$. Lidé jsou otroky náhody, jsou chyceni do pasti nepředvídatelnosti.

Česko-francouzský spisovatel už od svého románového debutu tematizuje otázku náhody a nedorozumění, které byly vpleteny do tkáně příběhů Kunderových hrdinů. Je jí např. jako „žert“ myšlená pohlednice demaskovaná jako projev třídního neprátelství (Žert) nebo záhadná modrá tabletka, která může způsobit smrt (Valč́k na rozloučenou). Každá rekvizita může $\mathrm{v}$ odlišném kontextu získat jiný význam, který může být i nadále měněn. Záměr se u Kundery velmi snadno zvrtne ve svůj pravý opak a získá úplně jiné vyznění. Je tomu tak i v př́ípadě plánu napravení Ludvíka u „černých baronư“, kde drsné podmínky učiní z komunisty rebela a anarchistu přesvědčeného o tom, že každý systém je ve své podstatě lživý. Krutá Ludvíkova pomsta se nepodařila a obrátila se proti samotnému strůjci, což hrdina Žertu hořce komentuje slovy: „Život se mi vysmíval, když mi poslal připomínku mého životního nezdaru právě $\mathrm{v}$ podobě milenky tohoto muže, kterého jsem den předtím

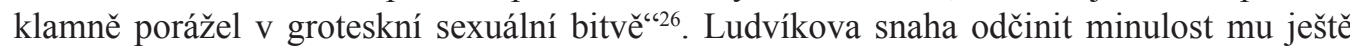
trpčeji připomněla marnost lidského údělu, nemožnost vrácení času stejně tak jako nemožnost napravení křivd. Tím, že svedl Zemánkovu manželku, nezranil svého úhlavního nepř́itele, ale jen statisty divadla náhod ${ }^{27}$. Jan Lopatka právě v paradoxnosti a programové omylnosti osudu vidí jistý organizující princip skutečnosti: „A «žert» neodolatelně pokračuje, použiji slov autorových, žert se obludně množí, stává se základním principem osudu: omyl jakožto organizující prvek; všechno je jinak, všechno má svou druhou a zcela odlišnou tvář

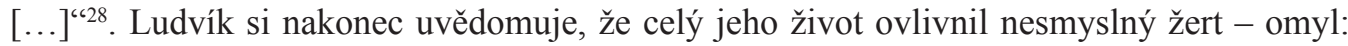
„A pocítil jsem děs, že věci vzniklé omylem jsou stejně skutečné jako věci vzniklé právem a nutně “ 29 a propadá pocitu deziluze ze života. Zdá se, že hrdina je najednou uvězněn ve své vlastní minulosti. Je si vědom toho, že za nic nemůže, ale je schopen pouze dál pokračovat $\mathrm{v}$ řadě omylů. Je jen trpným objektem něčího krutého žertu. Je jako dítě, které si samo ještě neumí zapnout kabát, a tak první knoflík dává do nesprávné dírky, což pak způsobí, že celý kabát je zapnutý nakřivo. Jeden nepatrný čin, jeden špatný krok může mít tragické důsledky. Ludvík je vystaven celé krutosti osudu, když musí podstoupit velký trest za malé provinění. Tíhu Ludvíkovy situace uchopila Sylvie Richterová, která odhalila nesmyslnost hrdinova počínání:

${ }^{24}$ M. Kwiek, Richarda Rorty'ego postmodernistyczny świat ironii, op. cit., s. 64-65.

25 R. Rorty, Nahodilost, ironie, solidarita, Praha 1996, s. 23.

26 M. Kundera, Žert, Brno 2007, s. 308.

27 P. Steiner, Ironie dějin: Žert Milana Kundery, [v:] idem, Lustrování literatury. Česká fikce v politickém kontextu, Praha 2002, s. 232.

28 J. Lopatka, Literatura speciálních funkcí, [v:] idem, Předpoklady tvorby, Praha 1991, s. 51.

${ }_{29}$ M. Kundera, Žert, op. cit., s. 319. 
Hrdina Žertu nenajde nikdy odpověd' na otázku, je-li jeho životní příběh dílem omylu nebo zákonitosti. Ví jenom, že se stal obětí křivdy, chce ji napravit, ale nezmůže se na nic jiného než na to, že v soukromém pokusu o odvetu sestrojí v menším měřítku věrnou kopii téhož křivého mechanismu: jeho omyl, zbytečnost a neodčinitelnost ${ }^{30}$.

Paradox žertu, špatného vtipu osudu, proniká do nejhlubších rovin románové skutečnosti. Omyly, náhody a nedopatření tvoří jistý řád, proti němuž hrdina není schopen bojovat. Nejsou to omyly samotného hrdiny, ale všech lidí, každého, koho hrdina na své cestě potkal: „Ty omyly byly tak běžné, a tak všeobecné, že naprosto nebyly výjimkou nebo ,chybou' v řádu věcí, nýbrž naopak právě ony tvořily řád věcí' ${ }^{\prime 31}$. Mezi činy a iluzemi o činech, mezi pravdou a lží, mezi činem a jeho interpretací zeje hluboká propast ${ }^{32}$.

Kundera ve svých románech velmi přesně zaznamenává mechanismus odloučení činu od původních záměrů. Na př́kladu toho, co se odehrávalo v Československu po roce 1948, nepř́mo účtuje se svým vlastním mládím, se svými vlastními iluzemi. „A tehdy ti mladí, chytř́i a radikální lidé měli najednou divný pocit, že poslali do světa čin a ten začal žít svým vlastním životem, přestal se podobat jejich představám a nedbal na ty, co ho zrodili“‘33. Takové činy, které se nedají odčinit, osudové činy pronásledující hrdiny Kunderových próz připomínají sněhové koule, které na sebe nabalují stále více sněhu, mění svou podstatu a najednou mají ničivou sílu a dokážou smést všechno a všechny, které na své cestě potkají.

Téma tragického řetězu událostí patří opět k jedněm z klíčových problémů v Kunderově tvorbě jako takové. Spisovatel o něm také píše ve svém slovníku slov a pojmů, hledaje pohnutky lidí, kteří uvěřili v komunismus: „[...] aspoň někteří jednali vedeni smyslem pro zodpovědnost za čin, který kdysi poslali do světa a jehož otcovství nechtěli popř́ít, hýčkajíce stále naději, že budou s to ho opravit, vychýlit ho, vrátit mu smysl. Čím víc se tato naděje ukazovala iluzorní, tím více vystupovala najevo tragika jejich existence ${ }^{\text {(34 }}$. Vrácení smyslu zde neznamená retušování, ale opravdový návrat $\mathrm{k}$ původnímu naplnění záměrů. Člověk se tedy v Kunderově pojetí stává bezbranným rukojmím vlastních činů, za něž nemůže nést zodpovědnost, protože mezitím byly zdeformovány a získaly jiné vyznění. Ale zároveň paradoxně za tyto činy, které už nepovažuje za své, onu zodpovědnost nést musí. Hrdinové Kunderových próz se nacházejí v zajetí svých činů, nejsou vybaveni přirozenou lidskou schopností prostě zapomínat na to, co bylo. Zapomnění, jak píše Paul Ricoeur, může být, stejně jako pamatování si, něčím pozitivním, vysvobozujícím, ale také něčím negativním ${ }^{35}$.

Vrat'me se však k Rortymu, který zastává názor, že ve světě neexistuje nic, co by nebylo výtvorem času a náhody, a tímto tvoří svéráznou metafyziku kontingence ${ }^{36}$. Náhoda

30 S. Richterová, Tři romány Milana Kundery, [v:] eadem, Slova a ticho, Mnichov 1986, s. 37.

31 M. Kundera, Žert, op. cit., s. 319.

32 Kundera sám je jako autor přecitlivělý, co se interpretace jeho děl a také samotné formy literárního textu týče. Podrobněji o tom píše Roman Kanda v textu Vladislav Vančura a Milan Kundera aneb Úskali dokonalosti (,Bohemica Olomuciensia Symposiana 4“ 2010, s. 121-126).

33 M. Kundera, Kniha smichu..., op. cit., s. 15.

${ }^{34}$ M. Kundera, Slova, pojmy, situace, op. cit., s. 60.

35 P. Ricoeur, Pamięć, historia i zapomnienie, Kraków 2006, s. 661.

36 M. Bosak, Metafizyk kontyngencji, „Sofia“ 2011, roč. 11, č. 11, s. 180. 
nic nevysvětluje, je jen výsměchem všem lidským záměrům a plánům. Uplatnění této teze lze najít právě u Kundery, jehož tvorba, co se vzniku týče, patři do období před zveřejněním Rortyho esejů. Kundera zachycuje lidskou touhu po řádu, po trvalém systému, po smyslu a principu, který bude platit navždy i v každém jednotlivém př́padě. Kundera zároveň ví, že tato lidská touha je marná.

Na principu náhody, která formuje lidské činy a řídí lidské osudy je vystaven celý román Valčik na rozloučenou. Růžena chce utéct ze světa, který ji omezuje, ze světa malého lázeňského městečka plného neplodných žen. Nakonec z onoho světa opravdu utíká, a to s konečnou platností, proti své vůli, nebot’ je „náhodou“ zavražděna Jakubem, jenž právě odjíždí do ciziny. Jakub paradoxně je i není vrahem. „Není pravda, že byl vrahem jen tak krátce. Je a zůstane jím až do smrti. Nebot’ není důležité, zda bleděmodrá tableta byla či nebyla jedem, důležité je, že byl o tom přesvědčen, a že ji přesto podal neznámé ženě a neudělal nic, aby ji zachránil“"37. Jeho konání připomíná ruskou ruletu - o všem rozhodne náhoda. Ale pravdou je, že to byl on, kdo do revolveru vložil onen osudový náboj. Byl to on, kdo „si zahrával“ s modrou tabletkou. Hry, kterým Kundera vystavuje své hrdiny, nejsou stavěny na principu agonálním - podle třídění Rogera Cailloise ${ }^{38}$. Nejsou v nich podstatné a rozhodující lidské osobní schopnosti, jako je lidská moudrost, předvídavost, pamět', rychlost, zkušenost atd. O vítězství (nebo spíše o výsledku hry, nebot' u Kundery se hrdinové nedělí na vítěze a porážené, spíše ji všichni v jistém ohledu prohrávají) nerozhodují skutečné výchozí podmínky, ale právě náhoda. Během četby Kunderových textů se nám vybavují slova biblického Kazatele: „Když jsem se rozhlédl pod sluncem, viděl jsem, že běh nezáleží na rychlých a boj na statečných, ba ani živobytí na moudrých, bohatství na šikovných a př́zeň na zkušených - o všem rozhoduje chvíle a náhoda“. Jak již bylo řečeno, na výsledek hry nemají vliv hráči, člověk může jen riskovat a v hloubi srdce doufat, že všechno dopadne podle jeho plánů.

Záměry se příkře rozcházejí s výsledky. Jakub je hluboce přesvědčen, že najde novou vlast, že ho s Československem už nic nespojuje. Ale poslední moment před odjezdem zcela změní jeho perspektivu nahlížení na tuto otázku: „Ještě včera si myslil, že to bude okamžik úlevy. Že odtud odjede rád. Že odjede odněkud, kam se narodil omylem a kam vlastně nepatří. Ale v této chvíli věděl, že odjíždí ze své jediné vlasti a že žádná jiná není‘39. Ve struktuře příběhu je vidět, že v každém činu i idejích je obsažen zárodek jejich zkázy, jejich konce.

Nejpříkřejší je však propast mezi činem a jeho interpretací. Kunderovým hrdinům náhoda občas přeje: např. maminčina psychická krize (Život je jinde) spojená s rozchodem s malířem je interpretována jako reakce na kruté události po Heydrichiádě ${ }^{40}$. Otec hlavního hrdiny přichází k posteli, dívá se matce soucitně do očí a kontext celé situace získává zcela jiný význam. Matka však proživá rozchod s milencem, nikoli tragické válečné události. Mladý Jaromil je označen za slibného umělce, protože kreslí lidi s hlavami psů, ale nikdo neví, že opravdový důvod je mnohem banálnější - chlapec prostě neumí nakreslit lidský obličej. Stejným způsobem jinou interpretaci získává Jaromilův pokus o oslovení velkého

\footnotetext{
${ }^{37}$ M. Kundera, Valčík na rozloučenou, Brno 1997, s. 212-213.

${ }^{38}$ R. Caillois, Hry a lidé: maska a závrat', Praha 1998, s. 32-34.

${ }^{39}$ M. Kundera, Valčik na rozloučenou, op. cit., s. 226.

${ }^{40}$ Idem, Život je jinde, Toronto 1979, s. 64.
} 
básníka. Chlapec mu posílá odstřižená telefonní sluchátka. Nejdřive to měla být pokorná prosba o jeho reakci, o pouhou odpověd' na Jaromilův dopis, ale po rozhovoru s kamarádem Jaromil dochází ke zcela protikladnému vysvětlení: „Ale po rozhovoru se spolužákem, který následoval (a on si byl jist, že to nebyla náhoda!) hned poté, dal jeho poetickému činu opačný smysl: nebyl to dar a prosebná výzva, nikoli, on básníkovi pyšně vracel všechno marné čekání‘"41. Samotný hrdina tak velmi snadno mění význam vlastního činu.

Svobodu, jak píše Richard Rorty, lze chápat jako uznání nahodilostiti ${ }^{42}$ a v tomto pojetí jsou hrdinové Kunderových próz ve většině případů tragicky nesvobodní. Nesouhlasí s nahodilostí, bouř́i se proti ní, chtějí být strůjci svých osudů, ale většinou se mění v loutky v rukou nepředvídatelností a náhod. Kundera ukazuje, že člověk je bezmocný, nemůže ovládnout tvar, formu a obsah svého života ${ }^{43}$, že jeho identita je proměnlivá, což je zdrojem frustrace a utrpení. Tato vize lidské nedokonalosti zůstává v rozporu s tím, co navrhl Paul Ricoeur, který nabízí narativní koncepci akceptující proměny lidského subjektu v průběhu času. Každý lidský subjekt vytváŕí svůj neopakovatelný narativ, který chce sdílet s jinými lidmi, každý člověk má ke sdělení svou jedinečnou, neopakovatelnou historiii" ${ }^{44}$. Člověk v tomto ohledu je subjektem dynamicky se měnícím, subjektem, který je v neustálém dialogu s ostatními lidmi, což však neznamená, jak je u Kundery mnohokrát zdůrazněno, že je jakýmsi způsobem nekoherentní. Touha po stabilitě, neměnnosti, jisté dokonalosti, která zaznívá v Kunderově tvorbě, nepředstavují pro Ricoeura valnou hodnotu, protože lidský subjekt je jistým způsobem výsledkem dialogů, které vede s ostatními, každý subjekt je určitou perspektivou, a právě v dialogu se tyto perspektivy křižují a doplňu$j^{4}{ }^{45}$. Člověk, jak ho vnímá Kundera, není však plnoprávným subjektem, často je pasivní a je spíše objektem a dokonce obětí - obětí okolností, náhod, a také interpretací ostatních lidí. Právě v tomto je vidět tragickou pasivitu každého člověka - lidé jsou pasivní, protože o ničem nerozhodují. I když se o něco snaží, i když se jim zdá, že sedí u kormidla dějin, nakonec se ukáže, že byli jen hříčkou dějin. Naplňuje se osud Středoevropana hozeného mezi velikány, člověka nesouhlasícího se svou podřazenou pozicí. Nahodilost hodnot, cílů a výsledků jejich jednání, nesouhlas, a dokonce i kolísání mezi záměrem a činem, mezi činem a jeho interpretací tvoří jeden ze základů tragického údělu Středoevropana, a v širším měřítku každého člověka. Právě proti takovému chápání náhody, proti existenci fáta protestoval v eseji Český úděl Václav Havel, když napsal, že my sami jsme strůjci svého osudu, z našeho osudu nás nikdo není schopen vysvobodit a nelze se vymlouvat ani na fátum ani na geografickou polohu ${ }^{46}$. O Kunderově uvažování o náhodách a jejich podílu na lidském údělu vypovídá hořká citace z povídky Nikdo se nebude smát zařazené do sbírky Směšné lásky:

41 Ibidem, s. 182.

${ }^{42}$ R. Rorty, Nahodilost, ironie, solidarita, op. cit., s. 28-29.

${ }^{43}$ J. Goszczyńska, Wolność w sporze z nieśmiertelnościa. (Milan Kundera Nieśmiertelność), [v:] eadem, Stawni i zapomniani. Studia z literatury czeskiej i stowackiej, Warszawa 2004, s. 138-139.

${ }^{44}$ P. Ricoeur, O sobie samym jako o innym, Warszawa 2005, s. 189.

${ }^{45}$ Ibidem, s. 83.

${ }^{46}$ V. Havel, Český úděl, „Host do domu“ 1969, roč. 15, č. 15, s. 23. 
Najednou jsem chápal, že je to jen moje iluze, když jsem si myslel, že si sami osedláváme příběhy a řídíme jejich běh; že to možná vůbec nejsou naše příběhy, že jsou nám spíš odkudsi zvnějšku podsunuty; že nás nikterak necharakterizují; že nemůžeme za jejich prapodivnou dráhu; že nás unášejí jsouce odkudsi řízeny jakýmisi cizími silami; ne, nemyslím nadpřirozenými silami nebes, ale silami lidí samých, kteří když se spojí v celek, jsou si pak pohříchu stále sami sobě cizími nebesy ${ }^{47}$.

Náhoda, za níž nese zodpovědnost jeden člověk, je malicherná, nemůže řídit běh světa, ale několik náhod propojených v těsnou a spletitou sít' se mění v nepřekonatelný nástroj proměny osudu jednotlivců. Zde je vidět pesimistické vyznění Kunderovy vize světa - hrdinové jeho próz se nemohou smířit s tím, že nelze ovládat jednou učiněné věci, že tyto věci žijí pak svůj život a podléhají neustálým hodnocením a interpretacím. Opravdová forma každé věci, předmětu, subjektu vzniká právě, jak uvádíme s Charlesem Taylorem, v průsečíku mezi objektem a subjektem tento objekt hodnotícím ${ }^{48}$. Podle Taylora lidská bytost není soběstačným subjektem, formuje se právě během interakce a dialogu. Hrdinové Kunderových próz však touží po takové soběstačnosti - chtějí vytvářet obraz sebe sama přesně podle pravidel, které sami určí. Nechtějí, aby tento obraz podléhal nějakým vlivům vnějšího světa. Tím pádem postavy Kunderových románů trpí problémy typickými pro současného člověka, který se, jak píše francouzská filozofka Chantal Delsol, dostal do pasti soběstačnosti a není schopen budovat s ostatními lidmi dialog a nějaké společné zázemí, a proto se nachází ve stavu tragické nerovnováhy ${ }^{49}$. U Kundery nenajdeme souhlas a akceptaci lidské slabosti. Hrdinové jeho prozaické tvorby chtějí být v jistém slova smyslu jedinými konstruktéry a interpretátory svých osudů, definitivními tvůrci svého života.

Smích či žert se mění v úšklebek, jistota v nejistotu, to, co je stabilní, přechází najednou v nestálost. Člověk zobrazený v Kunderově próze se stává součástí „,vyšší hry“, a svět, v němž člověk žije, je zobrazen jako hřiště. Člověk sám hraje, ale ,je jím také hráno”, to znamená, že je vystaven osudu i principu náhody. Překračování hranic, porušování pravidel, modifikování toho, co bylo dříve dohodnuto, deformace činů a záměrů ke hře prostě patří. Nic není naším soukromým majetkem - ani naše minulost, ani dopisy, které jsme napsali, ani činy, kterých jsme se dopustili. Všechno se člověku dříve nebo později odcizí, všechno bude podrobeno interpretacím a dezinterpretacím. Naše soukromé př́běhy, narativy v pojetí Paula Ricoeura, nejsou u Kundery cestou k pochopení vlastní identity, nejsou cestou k druhému člověku, ale spíše uzavírají lidskou bytost před okolním světem a činí ji zranitelnou. Hrdinové Kunderových próz chtějí spíše mlčel, zamlčovat jisté události, své jisté činy, a tímto nechtějí tvořit ricoeurovskou identitu vyprávění, čehož výsledkem je, že jejich vlastní identita je zdrojem frustrace, protože ji nejde „zkrotit“ - prostě neakceptují dynamičnost totožnosti a lidskou touhu po pravdě. Vize světa, kterou Kunderovy romány poskytují, není zdaleka optimistická, je prostoupena démonem pochybností, ale právě v tomto existenciálním tragismu se zdá být, i přes všechny výhrady, pravdivá.

\footnotetext{
${ }^{47}$ M. Kundera, Směšné lásky. Tři melancholické anekdoty, Praha 1963, s. 93.

48 C. Taylor, Źródta podmiotowości. Narodziny tożsamości nowoczesnej, Warszawa 2001, s. 347-349.

${ }^{49}$ C. Delsol, Esej o człowieku późnej nowoczesności, Kraków 2003, s. 67-68.
} 


\section{Bibliografie}

Bosak M., Metafizyk kontyngencji, „Sofia“ 2011, roč. 11, č. 11, s. 175-183.

Caillois R., Hry a lidé: maska a závrat', Praha 1998.

Connerton P., Seven Types of Forgetting, „Memory Studies“ 2008, č. 1, s. 59-71.

Češka J., Ironiczna bezdomność Bohumila Hrabala a thumiona tęsknota za domem Milana Kundery, „Porównania” 2012, roč. 11, č. 11, s. 89-99.

Chvatík K., Romány Milana Kundery a krize jazyka, „Tvar“ 1990, č. 5, s. 1, 4-5.

Delsol C., Esej o człowieku późnej nowoczesności, Kraków 2003.

Goszczyńska J., Wolność w sporze z nieśmiertelnościa. (Milan Kundera Nieśmiertelność), [v:] J. Goszczyńska, Stawni i zapomniani. Studia z literatury czeskiej i słowackiej, Warszawa 2004, s. $135-145$.

Haman A., Hledání vlastního života, [v:] A. Haman, Tři stálice moderní české prózy: Neruda, Čapek, Kundera, Praha 2014, s. 272-279.

Havel V., Český úděl, „Host do domu“ 1969, roč. 15, č. 15, s. 20-23.

Kanda R., Vladislav Vančura a Milan Kundera aneb Úskali dokonalosti, „Bohemica Olomuciensia Symposiana 4“ 2010, s. 121-126.

Kościukiewicz J., Wieczny powrót w twórczości Milana Kundery, [v:] Odbicie ważnych wydarzeń historycznych w języku $i$ w literaturze czeskiej, red. M. Balowski, Poznań 2010, s. 205-213.

Kubíček T., Kunderova estetická koncepce středoevropského románového dédictví. Základy, [v:] Cizinec - vyhnanec - prrístěhovalec, red. Z. Zemánová, L. Pořízková, Olomouc 2012, s. $295-298$.

Kubíček T., Středoevropan Milan Kundera, Olomouc 2012.

Kundera M., Směšné lásky. Tři melancholické anekdoty, Praha 1963.

Kundera M., Život je jinde, Toronto 1979.

Kundera M., Kniha smíchu a zapomnění, Toronto 1981.

Kundera M., Valčík na rozloučenou, Brno 1997.

Kundera M., Kastrujici stín svatého Garty, Brno 2006.

Kundera M., Nesnesitelná lehkost bytí, Brno 2006.

Kundera M., Žert, Brno 2007.

Kundera M., Slova, pojmy, situace, Brno 2014.

Kwiek M., Richarda Rorty'ego postmodernistyczny świat ironii, „Kultura współczesna. Teoria - interpretacje - krytyka“ 1993, roč. 1, č. 1, s. 56-66.

Le Grand E., Kundera aneb Pamét' touhy, Olomouc 1998.

Lopatka J., Literatura speciálních funkcí, [v:] J. Lopatka, Předpoklady tvorby, Praha 1991, s. 47-56.

Morawski S., Wyciag z Kundery i kilka o jego dziele domystów, „Sztuka i filozofia” 1996, č. 12, s. $5-16$.

Pieniążek P., Problem wiecznego powrotu $w$ filozofii Fryderyka Nietzschego, „Acta Universitatis Lodziensis. Folia Philosophica” 1988, č. 5, s. 179-201.

Ricoeur P., O sobie samym jako o innym, Warszawa 2005.

Ricoeur P., Pamięć, historia i zapomnienie, Kraków 2006.

Richterová S., Tř́i romány Milana Kundery, [v:] S. Richterová Slova a ticho, Mnichov 1986, s. 33-66.

Rorty R., Nahodilost, ironie, solidarita, Praha 1996.

Steiner P., Ironie dějin: Žert Milana Kundery, [v:] P. Steiner, Lustrování literatury. Česká fikce v politickém kontextu, Praha 2002, s. 225-248.

Taylor C., Źródła podmiotowości. Narodziny tożsamości nowoczesnej, Warszawa 2001. 


\title{
AGNIESZKA JANIEC-NYITRAI
}

\section{The grey zone between intentions and actions or a few notes about paradoxes of the human plans in Milan Kundera's prose}

\begin{abstract}
Summary
The aim of the study is to offer a slightly different view of Milan Kundera's prose and to recall the issues of memory and human activities as the subjects of constant interpretation and reinterpretation. Last but not least, the article examines human identity and the freedom of human decision-making. In the study, the theory of cultural oblivion is used as a strategy for building our own identity and subjectivity. Notably, since the 1960s, Kundera has dealt with these issues, which later became the subject of memory studies. Kundera has overtaken the memory boom which was highly popular for some years. Another important issue analysed in the study is the question of responsibility for one's own deeds, worlds, actions and the issue of the possibility of dialogue between people. All these issues are examined on the basis of Kundera's novels.
\end{abstract}

Keywords: Milan Kundera, novel, memory studies, dialogue, interpretation 